\title{
Sedimentology, Stratigraphy and Micropaleontology of Pre- and Early-Champlain Sea Fine-Grained Facies from the Foster Sand Pit, Ottawa, Ontario Sédimentologie, stratigraphie et micropaléontologie des faciès à grains fins glacio-lacustres et du début de la Mer de Champlain, sablière Foster, Ottawa, Ontario
}

\author{
Dana L. Naldrett
}

Volume 42, numéro 2, 1988

URI : https://id.erudit.org/iderudit/032724ar

DOI : https://doi.org/10.7202/032724ar

\section{Aller au sommaire du numéro}

\section{Éditeur(s)}

Les Presses de l'Université de Montréal

ISSN

0705-7199 (imprimé)

1492-143X (numérique)

Découvrir la revue

Citer cette note

Naldrett, D. L. (1988). Sedimentology, Stratigraphy and Micropaleontology of Pre- and Early-Champlain Sea Fine-Grained Facies from the Foster Sand Pit, Ottawa, Ontario. Géographie physique et Quaternaire, 42(2), 181-189. https://doi.org/10.7202/032724ar

\section{Résumé de l'article}

La sablière Foster laisse voir des sédiments glacio-lacustres et du début de la Mer de Champlain qui comprennent quatre litho-biofaciès. Les faciès, du plus vieux au plus récent, sont les suivants: Le faciès $n^{\circ} 1$ est composé de sable et d'un diamicton à stratification oblique qui se présente comme un épandage fluvio-glaciaire subaquatique tardiglaciaire. Le faciès $n^{\circ} 2$ est composé de silt laminé et de rythmites d'argile comprenant une faune peu abondante d'ostracodes \{Candona cf. C. subtriangulata): ce faciès a été mis en place dans un lac proglaciaire profond qui a précédé la Mer de Champlain. Le faciès $n^{\circ} 3$ est une argile silteuse d'aspect généralement massif avec quelques rares lamines renfermant les foraminifères Elphidium bartletti, Protelphidium orbiculare et Cassidulina crassa; ce faciès représente le premier dépôt de la Mer de Champlain mis en place à 30-100 $\mathrm{m}$ de profondeur; la paléosalinité était de $22-33 \%$ o. Le faciès $n^{\circ} 4$ formé de lits de sable et de boue mélangés, comprend un assemblage de microfossiles dominé par le complexe Elphidium Protelphidium, qui représente une séquence intertidale de régression. Au cours de sa mise en place, la profondeur d'eau s'est abaissée jusqu'à 10-30 m, et les eaux se sont progressivement dessalées jusqu'à 18-28 \%o. Dans cette étude, on reconnaît l'existence d'un lac proglaciaire précédant la Mer de Champlain. on attribue aux dépôts d'épandage subaquatique un âge supérieur à ce que l'on croyait auparavant et on fournit des renseignements sur le caractère changeant des eaux plus profondes du début de la Mer de Champlain fondés sur des preuves découlant de l'étude des sédiments et des microfossiles. 


\title{
Notes
}

\section{SEDIMENTOLOGY, STRATIGRAPHY AND MICROPALEONTOLOGY OF PRE- AND EARLY- CHAMPLAIN SEA FINE-GRAINED FACIES FROM THE FOSTER SAND PIT, OTTAWA, ONTARIO}

\author{
Dana L. NALDRETT, Department of Geography, Queen's University, Kingston, Ontario K7L 3N6.
}

\begin{abstract}
The Foster sand pit exposes pre- to late-Champlain Sea sediments containing 4 litho/biofacies. These are, from oldest to youngest: Facies 1-cross-stratified sand and diamicton deposited as late-glacial, ice-proximal subaqueous outwash. Facies 2-laminated silt and clay rhythmites with a sparse Candona cf. C. subtriangulata ostracode fauna deposited in a deep, proglacial lake preceding the Champlain Sea. Facies 3- massive to rarely laminated silty clay with dominant foraminifera Elphidium bartletti, Protelphidium orbiculare and Cassidulina crassa represents the first glaciomarine deposition in Champlain Sea water 30-100 m deep with a paleosalinity of 22$33 \%$. Facies 4- mixed bedding of sand and mud, with a microfossil assemblage dominated by the Elphidium/Protelphidium complex representing an intertidal offlap sequence. Water depths during deposition of Facies 4 dropped to $10-30 \mathrm{~m}$, and paleosalinity dropped to $18-28 \%$.. This study recognizes a pre-Champlain Sea proglacial lake, assigns subaqueous outwash deposits to an earlier time than previously believed and documents changes in bottom water characteristics of the early Champlain Sea based on sedimentary and microfossil evidence.
\end{abstract}

\section{INTRODUCTION}

Champlain Sea sediments and fossils have been the subject of intensive investigation for over 100 years. Studies in the Ottawa Valley, however, are not as common as in other areas of the OttawaSt. Lawrence Lowlands. This is particularly important since the upper Ottawa Valley is the limit of marine invasion and may be significant in assessing the interaction of Lake Algonquin, Lake Iroquois and the Champlain Sea.

Recent construction and sand pit operations exposed late Quaternary sediments in the Foster pit, Ottawa, Ontario (Fig. 1). The

Manuscrit reçu le 31 mars 1987; manuscrit révisé accepté le 30 octobre 1987
RÉSUMÉ Sédimentologie, stratigraphie et micropaléontologie des faciès à grains fins glacio-lacustres et du début de la Mer de Champlain, sablière Foster, Ottawa, Ontario. La sablière Foster laisse voir des sédiments glacio-lacustres et du début de la Mer de Champlain qui comprennent quatre litho-biofaciès. Les faciès, du plus vieux au plus récent, sont les suivants: Le faciès no 1 est composé de sable et d'un diamicton à stratification oblique qui se présente comme un épandage fluvio-glaciaire subaquatique tardiglaciaire. Le faciès $n^{\circ} 2$ est composé de silt laminé et de rythmites d'argile comprenant une faune peu abondante d'ostracodes (Candona cf. C. subtriangulata) ce faciès a été mis en place dans un lac proglaciaire profond qui a précédé la Mer de Champlain. Le faciès $n^{\circ} 3$ est une argile silteuse d'aspect généralement massif avec quelques rares lamines renfermant les foraminifères Elphidium bartletti, Protelphidium orbiculare et Cassidulina crassa; ce faciès représente le premier dépôt de la Mer de Champlain mis en place à $30-100 \mathrm{~m}$ de profondeur; la paléosalinité était de $22-33 \%$. Le faciès $n^{\circ} 4$ formé de lits de sable et de boue mélangés, comprend un assemblage de microfossiles dominé par le complexe Elphidium - Protelphidium, qui représente une séquence intertidale de régression. Au cours de sa mise en place, la profondeur d'eau s'est abaissée jusqu'à 10-30 m, et les eaux se sont progressivement dessalées jusqu'à 18-28\%. Dans cette étude, on reconnaît l'existence d'un lac proglaciaire précédant la Mer de Champlain, on attribue aux dépôts d'épandage subaquatique un âge supérieur à ce que l'on croyait auparavant et on fournit des renseignements sur le caractère changeant des eaux plus profondes du début de la Mer de Champlain fondés sur des preuves découlant de l'étude des sédiments et des microfossiles.

purpose of this paper is to investigate the sedimentology, stratigraphy and micropaleontology of pre- and early- Champlain Sea sediments exposed in this pit and to develop a depositional model for the facies observed.

\section{PREVIOUS STUDIES}

Previous studies have focussed on the subaqueous outwash facies of the ridges in the Ottawa area, and on the littoral deposits of the receding Champlain Sea (Fig. 2). Little work has been conducted on the earlier deposits of rhythmically laminated and massive silt and clay. Johnston $(1916,1917)$ noted its occurrence and distribution, dividing it into upper and lower clay. Gadd $(1961,1962)$ subsequently investigated the rhythmites exposed along the Rideau River near Uplands. He postulated that the late-glacial Rideau Valley was blocked by the Bowesville Moraine (now termed the South Gloucester Ridge, 


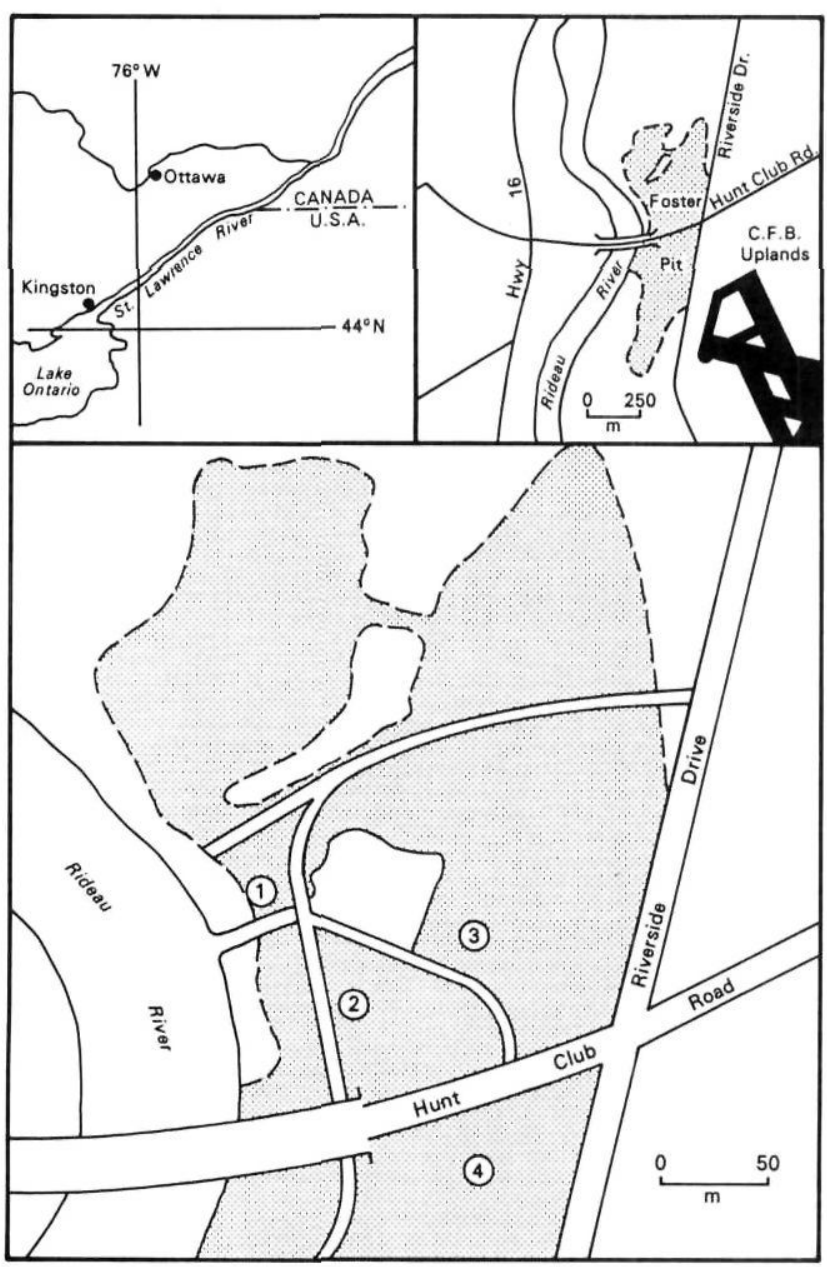

FIGURE 1. Location of sections in the Foster sand pit. Localisation des coupes dans la sabliere Foster.

Fig. 2) and drained southward toward the St. Lawrence Valley. Gadd suggested that in a stage just prior to marine submergence, the valley contained a glacial lake. Banerjee (1973) named the lower clay the Rideau River varves, and identified structures indicative of slumping at a delta front and turbidite deposits. Romanelli (1970) discovered the marine foraminifera Elphidium bartletti, Protelphidium orbiculare, Cassidulina islandica and Pseudopolymorphina novanglie in the upper clay at this locality.

\section{SEDIMENTOLOGY AND STRATIGRAPHY}

\section{FACIES DESCRIPTIONS}

To simplify discussion, sediments from the Foster sand pit have been grouped into facies 1-4, described below.

\section{Facies 1}

In all sections observed, basal sediments are either a tabular cross-bedded to rippled medium-grained sand (Fig. 4a) or a poorly sorted diamicton (Fig. 4b). At section 1 (Fig. 3) the sand is overlain by diamicton; at section 2 the diamicton is absent. Based on the stratigraphic position, fabric, poor sorting and the lack of sedimentary structures within the diamicton it is considered to represent a till flow. Till flow facies have been observed in association with interchannel sand facies of the Ottawa area ridges (Rust, 1982). Other coarse-

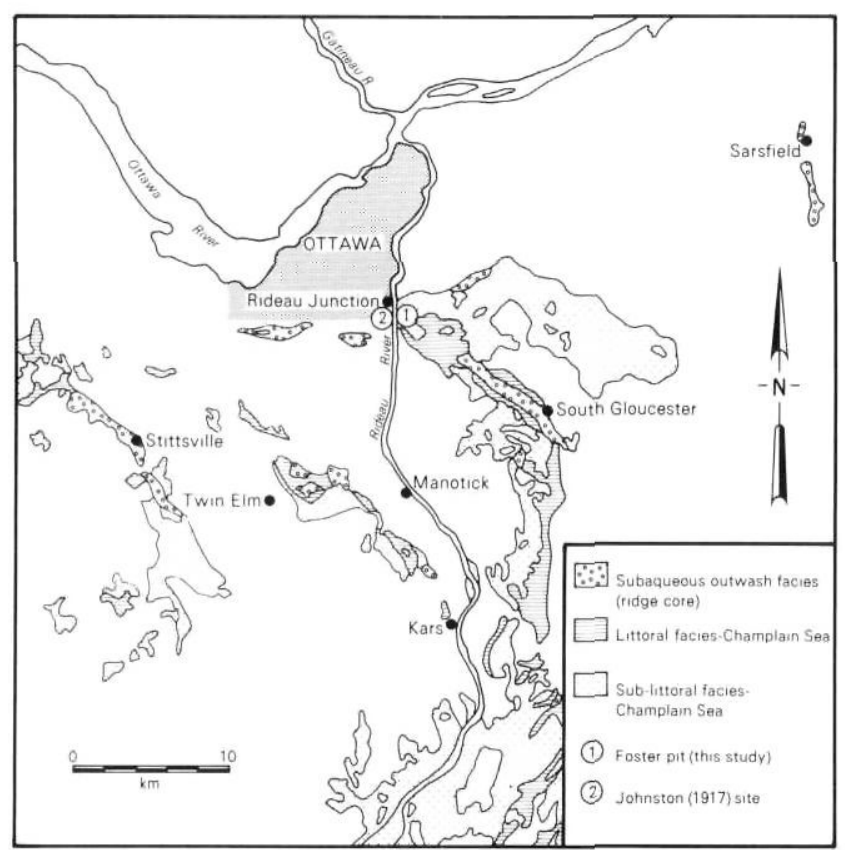

FIGURE 2. Subaqueous outwash and littoral facies of the Ottawa area (after Richard et al., 1977).

Épandage fluvio-glaciaire subaquatique et faciès littoral de la région d'Ottawa (selon Richard et al., 1977).

grained facies, such as proximal gravel, are clast-supported with large, imbricate clasts. In contrast, this diamicton is matrix-supported with smaller maximum clast size; and it has no preferred orientation of the larger clasts. Drilling studies show similar diamicton at the base of the South Gloucester Ridge (French and Rust, 1981; Graham and Jackson, 1982).

Section 2 sediments consist of a large-scale tabular set of crossbedded sand overlain by convoluted interbedding of fine silt or clay and silty sand. The large tabular set is $0.8 \mathrm{~m}$ thick and consists of well defined foreset, toeset and attenuating bottomset laminae. in places, the dune foresets can be traced through toesets into bottomsets (Fig. 4a). The rate of sedimentation of the suspended load was sufficient to form a fine sandy to silty drape over the dune front, in places merging into regressive ripples of the bottomset. The continuity between the foreset, topset and bottomset bedding indicates that these units are contemporaneous.

In the upper rippled sand facies, transitional ripples (Jopling and Walker, 1968) have low angle erosional scours merging into a lens of deformed ripples (Fig. 4c). This may be a large rip-up clast, although its origin is problematic. It is larger than common rip-up clasts $(1.5 \mathrm{~m}$ long and $30 \mathrm{~cm}$ high), and the heavy mineral laminations do not have normal (depositional) orientations.

Overlying the sand facies and transitional to the rhythmites above is convoluted interbedding of fine silt or clay and silty sand. These beds appear to be similar to the ripples below, but they have been disrupted by loading and slumping (Fig. 4d). At least two complete cycles occur where ripple amplitude decreases upward and laminations change from small type $\mathrm{C}$ ripple drift cross-lamination at the base to nearly planar lamination at the top (Fig. 4e). Banerjee (1973) described similar structures and attributed them to slumping at a delta front. Figure $4 \mathrm{e}$ illustrates the downslope movement, where travel was from left to right. Parts of the clay bed have become detached when slumping silty sand cut into the clay, separating part of the underlying bed. The cohesiveness of the clay caused the detached sediment 


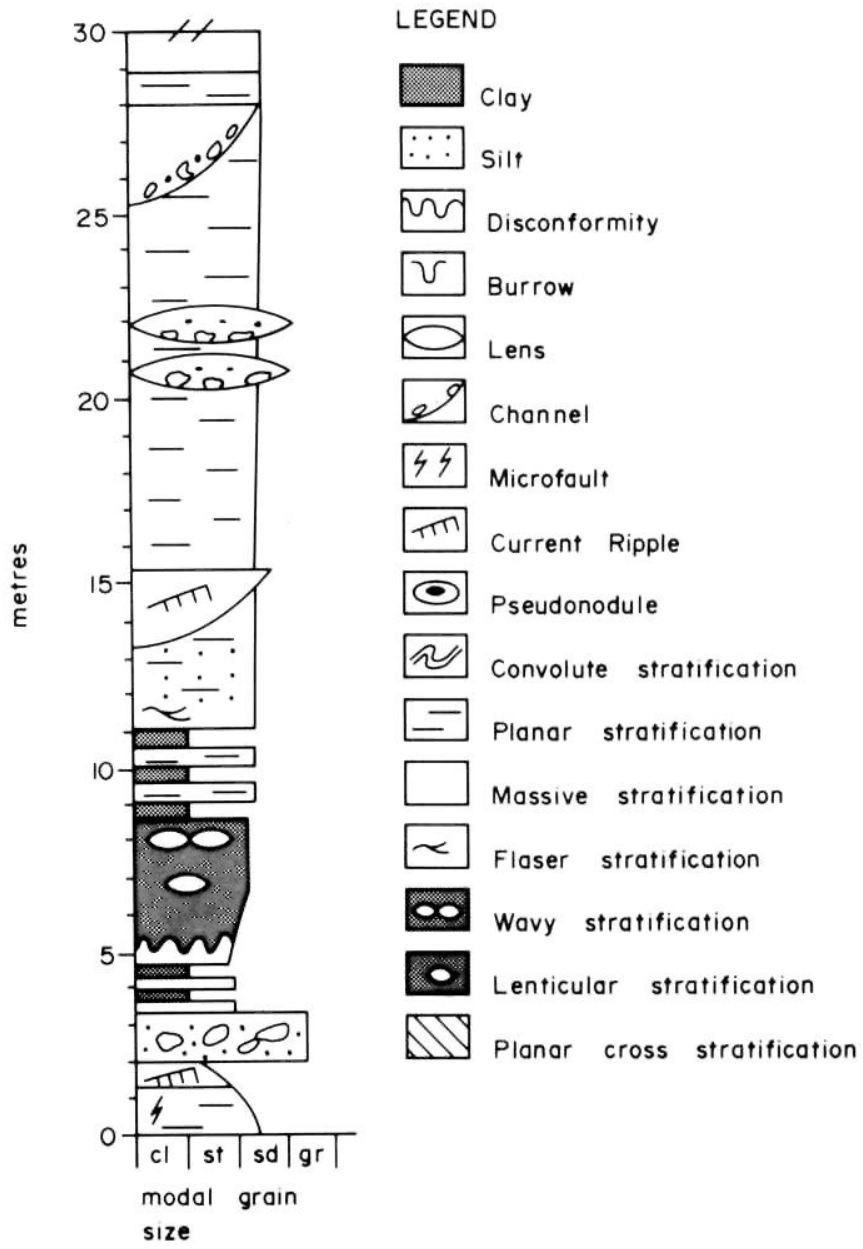

FIGURE 3. Generalized stratigraphic column of sediments exposed at the Foster pit, Ottawa, Ontario.

Colonne stratigraphique généralisée des sédiments de la sablière Foster, à Ottawa, en Ontario.

to form small spheres. Water escape structures formed as a result of rapid deposition of silty sand over clay (Fig. 4e). Trapped water could not escape through the clay, and was forced to travel upwards through the overlying sand.

At section 1 a lens of convolute laminated silt and clay pinches out above the till flow. Thickness varies up to $20 \mathrm{~cm}$, and in places convolutions form crude pseudonodules. In contrast to the obvious slump features of section 2, these occur in a variety of orientations rather than the unidirectional deformation produced by slumping. The disrupted bedding may be the result of grounded ice shearing the underlying sediments, producing deformation in several directions (Fig. 4f).

Conformably overlying this disrupted bedding is an thin $(10 \mathrm{~cm})$ drape of laminated sand and silt, which represents the first rhythmite deposition. The drape consists of massive to faintly laminated medium sand with the middle $5 \mathrm{~cm}$ composed of laminated silt and clay. Isolated pseudonodules composed of laminated silt and clay occur in the sand, and rarely exceed $10 \mathrm{~cm}$ in size.

\section{Facies 2}

Rhythmites, previously described as varves by Banerjee (1973) and Gadd (1961, 1962), are restricted to a $1 \mathrm{~m}$ section overlying sediments of Facies 1 (Figs. 5, 6 and 7a). Naldrett $(1986,1988)$ has determined deposition to be episodic rather than annual, consequently laminated silt and clay deposits are here termed rhythmites. Sections are composed of silt and clay with occasional lenses of diamicton which occur in the central portion of the sequence. Several exposures were excavated to determine the size and shape of the diamicton. Lenses range up to three metres in length and $40 \mathrm{~cm}$ in thickness (Fig. 7b). It is assumed that the material is ice-rafted, although there is no clear evidence of sorting by rain-out processes.

Undulose bedding and ripples are the dominant sedimentary structures within the silt and clay. Figure 7c illustrates a typical rhythmite series $20 \mathrm{~cm}$ thick. The rhythmites are predominantly silt with occasional sand and rare clay layers. Most textural variation occurs from very fine to medium or coarse silt. Silt layers are often undulose and form long wavelength ripples, with all contacts smooth and gradational. In rare cases, fine-grained sediments display small load structures when overlain with coarser material. Microfaults occur randomly throughout the silt layers. Displacements are usually a few $\mathrm{mm}$, i.e. two to three times the lamination thickness. Faults are restricted to single beds, suggesting a syndepositional origin. Coarse (sandy) layers are poorly graded and have a sharp contact with the overlying silt. Sorting is good throughout all layers. Small clasts up to $3-4 \mathrm{~mm}$ in diameter commonly occur at the top of the sand laminations, and never occur in the clay. These are interpreted as dropstones deposited from summer melt of surface ice. In the rhythmite classifications of Banerjee (1973) and Lajtai (1969), these would be silty or graded to complex, respectively.

\section{Facies 3}

Overlying the rhythmites is a well documented coarsening upward sequence (Gadd, 1977). The portion described here represents the lower, fine-grained facies where muds predominate. Here there is a transition from a basal laminated clay to an apparently massive upper clay (Fig. 7d). A rippled silt bed between these two units marks the position of a disconformity separating non-marine rhythmites from massive marine silt and sand (Naldrett and Rust, 1984). Subsequent examination of fossil insects and plants in the silt indicates this material is younger than its designated stratigraphic position would suggest, however its absolute age remains unknown (Geological Survey of Canada Plant Macrofossil Report No. 84-25 by J. V. Matthews Jr. and GSC Fossil Arthropod Report No. 84-24 by J. V. Matthews Jr.).

$1.5 \mathrm{~m}$ above the contact with massive silt, juvenile Portlandia arctica occur. Of 35 individuals collected, all were less than $5 \mathrm{~mm}$ long, with the majority between $2-3 \mathrm{~mm}$ long. No adult remains were found. The close range in size and the samll size itself suggests a high juvenile mortality rate (Naldrett, 1988). Spat-kill must have occurred at an early stage, eliminating an entire generation of individuals. Hillaire-Marcel (1980) noted that Portlandia arctica are typical of early glaciomarine environments, however the early Champlain Sea must have been too harsh for even this hardy species.

\section{Facies 4}

Sedimentary structures were produced by the transition from a low to a high energy depositional environment. This created mixed bedding with a continuous series of lenticular, wavy and flaser beds formed by decreasing mud and increasing sand content.

Figure 8 a shows clustered, load casted ripples. The lower group are in the initial stage of deformation, while the upper group are clustered and load casted. They form when a number of ripples are loaded into weak mud at the same site; each new ripple presses the preceeding one further down and forward until a radial structure is created. Once locally weakened, the mud remains at reduced strength, permiting further deformation. If a suitable supply was in suspension, 

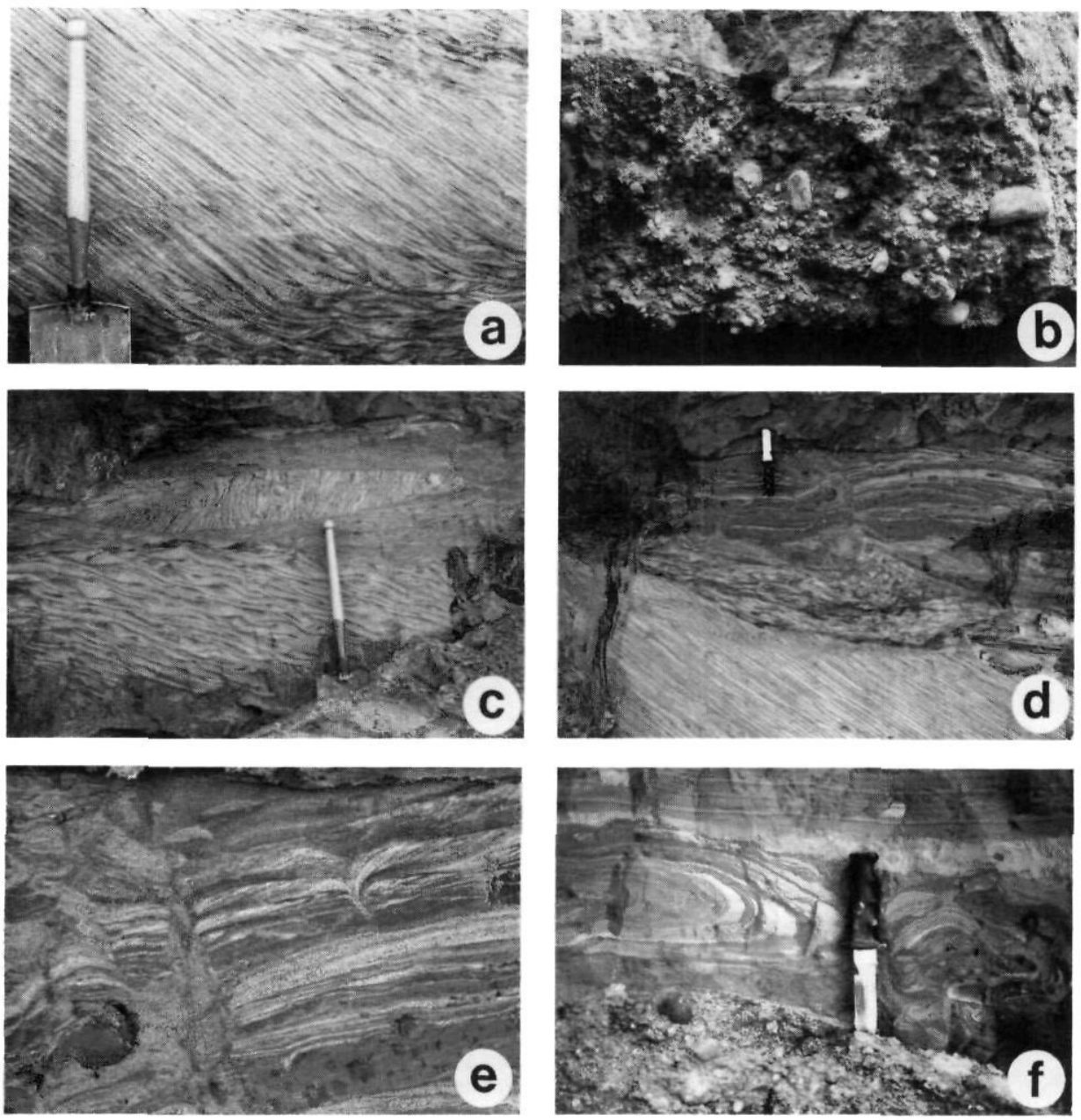

FIGURE 4. Sedimentary structures underlying the rhythmites: a) dune, section 2 ; b) diamicton, section 1 ; c) rip-up clast, section 2 , bedding shown by heavy mineral accumulations; d) convolute laminations, section 2; e) detail of fluid escape structures from $5 \mathrm{~d}$; $\mathrm{f}$ ) shear (ice-contact) structures, section 1.

Structures sédimentaires sous les rythmites; a) dune, coupe $n^{\circ} 2$; b) diamicton, coupe $n^{\circ} 1$; c) fragment d'arrachement, coupe $n^{\circ} 2$, les accumulations de minéraux lourds montrent le litage; d) laminations contournées, coupe $n^{\circ} 2$; e) détail des structures d'échappement fluidal de 5d; structures de cisaillement (de contact glaciaire), coupe $n^{\circ} 1$. the sand could penetrate the entire depth of the mud bed. The structures are thus syndepositional (Allen, 1982).

Gutter casts (Fig. 8b) were found in close proximity, immediately below one of several channels (shown in the stratigraphic column, Fig. 3). A corrasional origin for these features has been generally accepted. The best evidence for this is the striated bottom and sides and the presence of possible tools in the infillings. Unlike other reported casts, these were formed in relatively coarse sediment with a fine infilling. Gutter casts usually are found in muddy substrates where they have been scoured by coarser materials.

In the wavy to flaser bedded mud and sand, articulated Mytilus edulis, Macoma balthica, and Balanus crenatus were found in growth position. Larger Mytilus were located at the centre of the colony with smaller individuals growing on the periphery and overgrowing the larger shells. Macoma was also associated with the smaller Mytilus. A few Balanus encrusted the larger Mytilus. Two radiocarbon dates were obtained: Mytilus gave age of $10,100 \pm 100$ BP (BGS-885) and Macoma gave an age of 10,500 $\pm 180 \mathrm{BP}$ (BGS-886). These dates are in general agreement with previously obtained dates on mixed shell material and bone from the overlying sand unit (Naldrett, 1986).

As well as body fossils, trace fossil burrows are present (Fig. 8c). Burrow density is high, but intervening sediments have preserved primary bedding. Sediment within the structure is $1-2$ grade sizes smaller than the surrounding sediment. Spiral and intersecting mor- phologies suggest a biotic rather than physical origin. Density and size of the structures suggests that they may be polychaete rather than bivalve burrows. Polychaetes are rarely reported, but Wagner (1984) has noted them in the Ottawa area.

Much of the rippled, fine sand and silt has iron-stained beds of medium sand $5-10 \mathrm{~cm}$ thick spaced periodically $20-50 \mathrm{~cm}$ apart. This phenomenon has been noted in marine and non-marine environments, and usually involves periodic precipitation of manganese and iron, with the release of hydrogen sulphide from groundwater (Donovan and Lajoie, 1979). In this case, bands of iron have been precipitated. In other cases, the reaction geometry is different, forming rings around organic particles. Gadd (1971) noted similar deposits in the upper clay unit, calling them the black-mottled facies. This may result from precipitation around fecal pellets or other point sources of organic material capable of decomposition.

Concentration of available iron has also caused the precipitation of a burrow-like structure (Fig. 8d). Several factors suggest the structure is not a burrow. The size is too large- the only burrowing organisms known to exist in the sediment are bivalves and polychaetes, and all are much smaller than the structure. At least two laminae penetrate the structure and some bend downward, as occurs in fluid escape structures where sediment collapses after fluid release. It appears that the structure formed by precipitation of iron mobilized by groundwater flow through the beds described above. Water traveled through the overlying sand to the level where the underlying fine-grained 


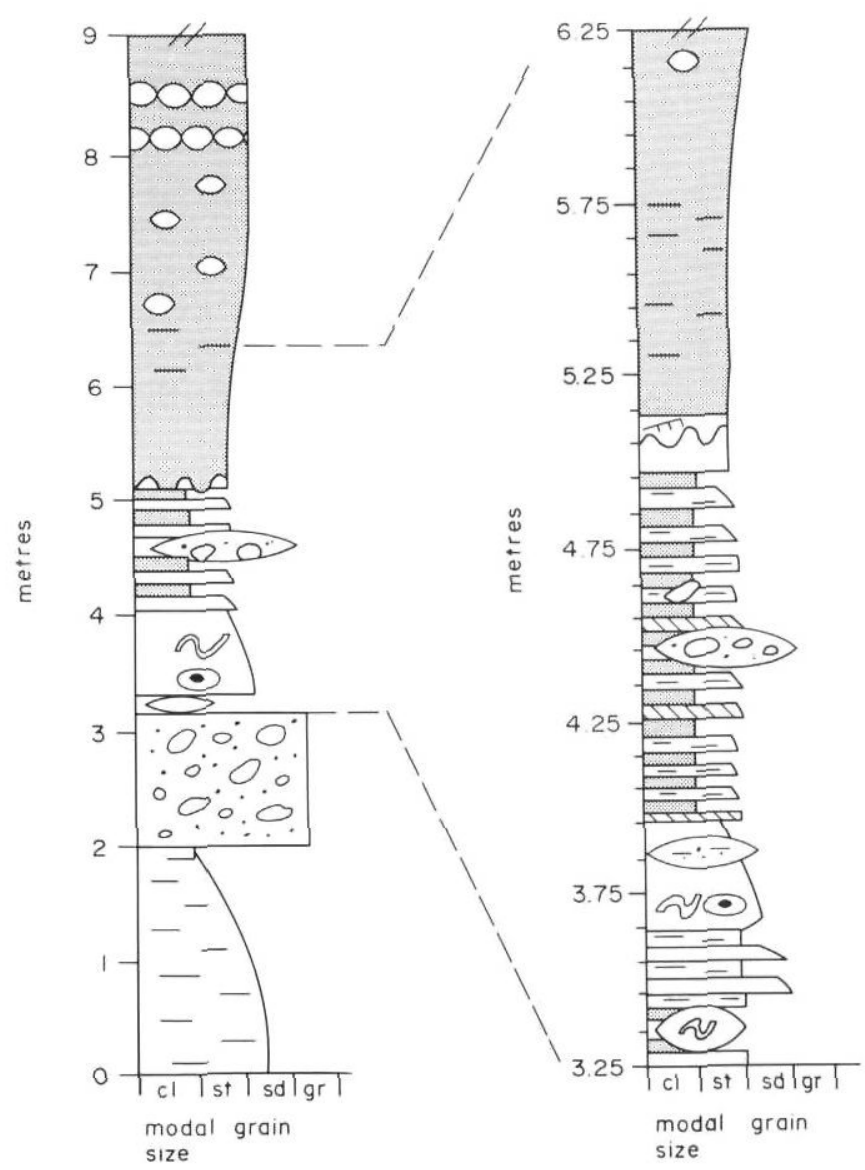

FIGURE 5. Stratigraphic column, section 1.

Colonne stratigraphique, coupe $n^{\circ} 1$.
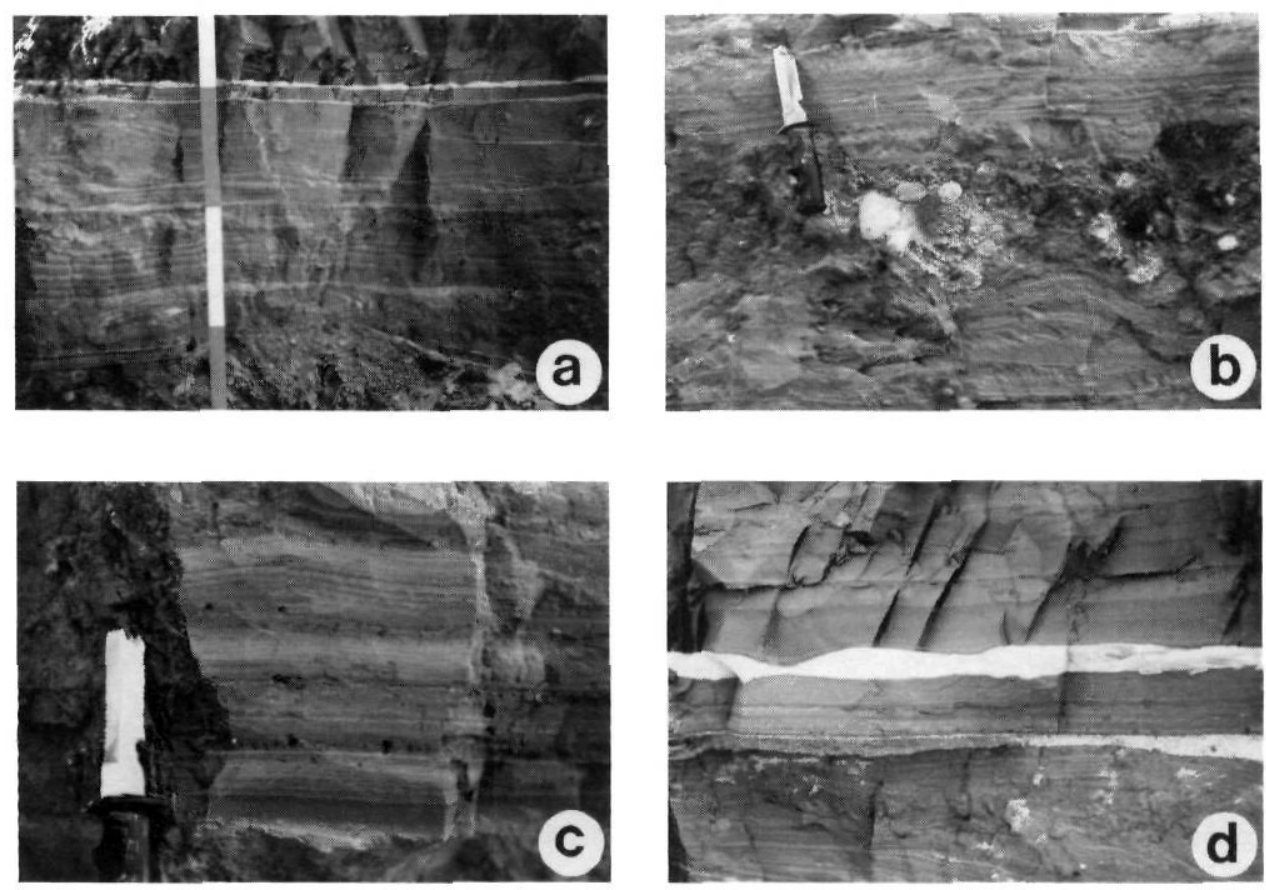

FIGURE 6. Stratigraphic column, section 2.

Colonne stratigraphique, coupe $n^{\circ} 2$.

9

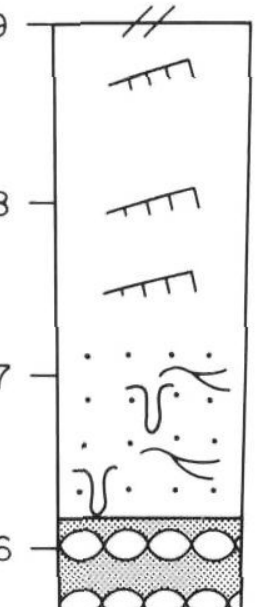

ֻ
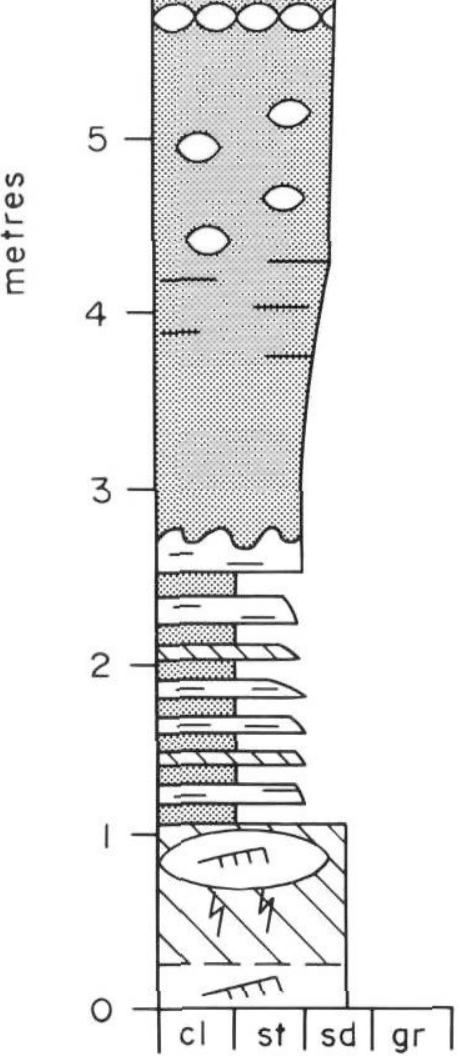

modal grain

size

FIGURE 7. Rythmite portion of section 1: a) general view of rythmites; b) lens of ice-rafted debris; c) details of rythmites laminations; d) rippled silt bed separating rythmites from overlying massive silt.

Partie de la coupe $n^{\circ} 1$ contenant des rythmites: a) vue générale des rythmites; b) lentilles de débris transportés par radeaux de glace; c) détail des laminations de rythmites; d) lit de silt ondulé qui sépare les rythmites du silt massif sus-jacent. 

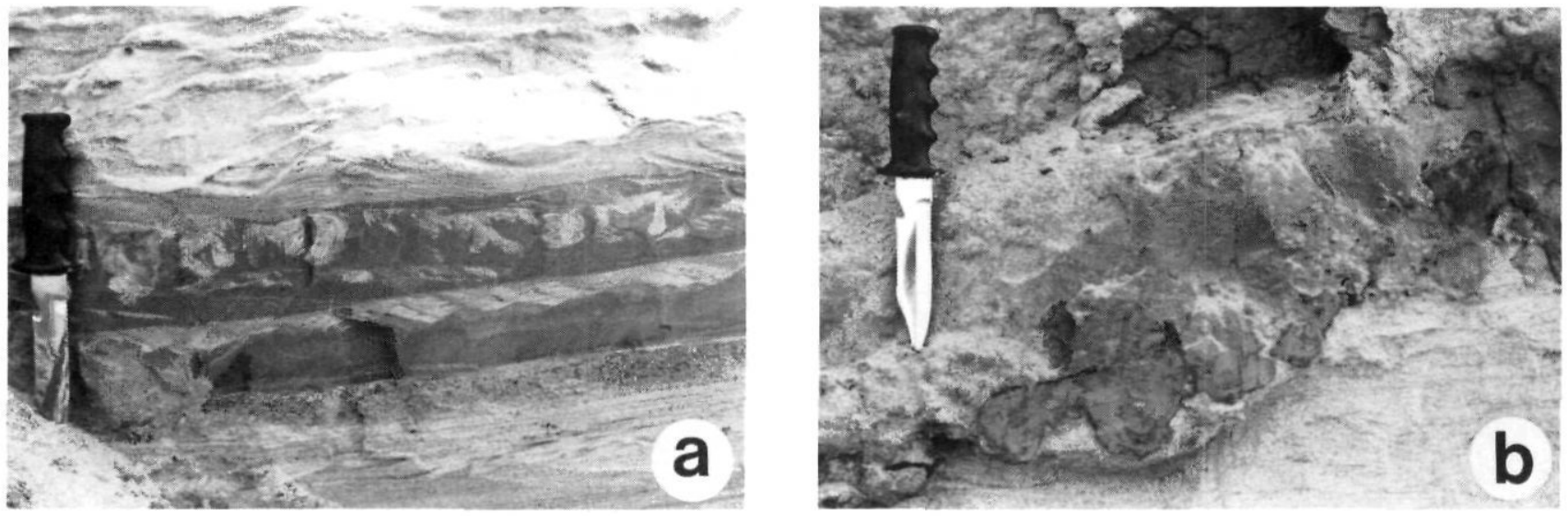

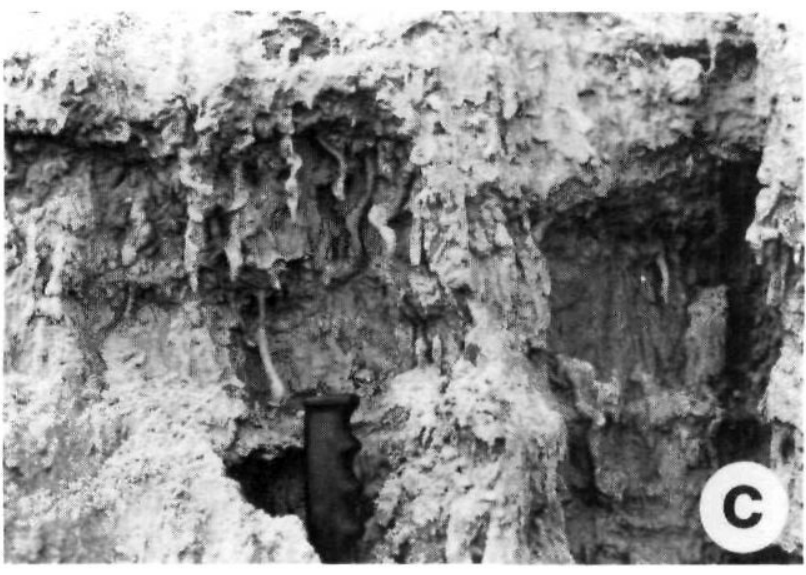

FIGURE 8. Sedimentary structures in sand and mud facies: a) load casted ripples, section 3 ; b) gutter casts, section $3 ;$ c) possible polychaete burrows, section $3 ;$ d) iron-stained burrow-like structure section 2.

sediments acted as a barrier. The structure was then created as available iron precipitated on the inside walls of the water flow path.

\section{MICROPALEONTOLOGY}

Additional information on environment(s) of deposition was obtained by examination of the microfauna. Unfortunately, the reproducibility of much of the Champlain Sea micropaleontology work is poor. Faunal distribution may be patchy, and it may be difficult to determine whether a sample is representative. Faunas may change rapidly within the same stratigraphic unit. At section 1, five samples taken one metre apart in the same bed yielded different fauna, although the dominant species are the same. Dominant species, however, are considered representative of the depositional environment. Variation in microfossil abundance is a function of the rate of sedimentation, diagenetic processes, and adverse environmental conditions at the time of deposition (Cronin, 1977). Low salinity, poor nutrient supply or strong currents may also affect abundance. Much of the previous work has been conducted on an inventory basis without regard to stratigraphic position, so that paleoecologic information is of limited use. Recent studies by Naldrett (1986) and Rodrigues and Richard (1986) have clearly demonstrated the value of an ecostratigraphic approach rarely used by others. The following discussion summarizes complete data

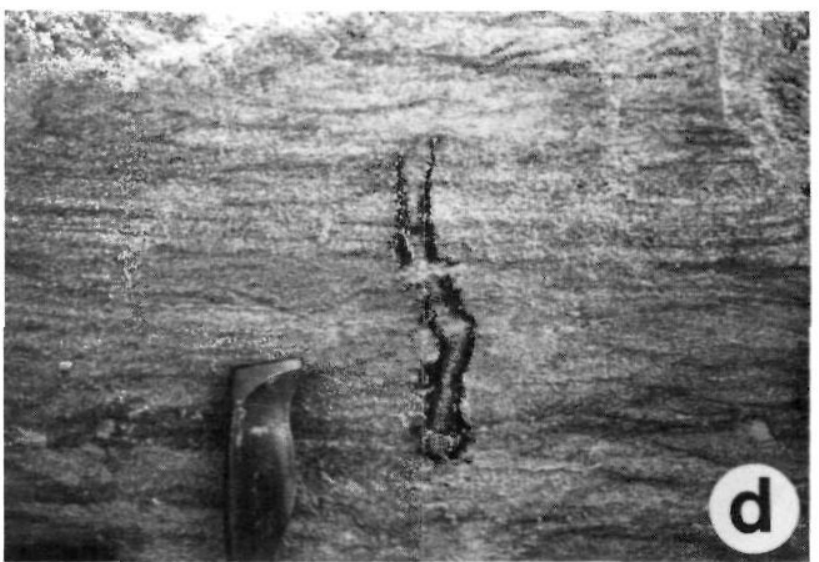

Structures sédimentaires du faciès de sable et boue mélangés: a) rides à moulages de boue, coupe $n^{\circ} 3$; b) moulure de gouttiere, coupe $n^{\circ} 3$; c) probablement un terrier de polychètes, coupe $n^{\circ} 3$; d) structure semblable à un terrier taché de fer.

on sample location, species number and stratigraphic position given by Naldrett (1986).

\section{Method}

Adequate recovery of faunal material is highly dependant upon processing technique. If methods are not clearly stated, it may not be obvious that a given faunal component is missing.

The following method was developed for processing foraminifera and ostracodes together. A $200 \mathrm{~g}$ sample is warmed on low heat for one to two hours (depending on clay content) in 2 I water with $30 \mathrm{ml}$ Quaternary-O (commercial detergent). The mixture is cooled and wet sieved with warm water through 20-, 100-, and 200-mesh sieves. The 20-mesh retains the largest forams and ostracodes, insects and macrofossil fragments (if present). Residue from the other sieves is then washed three or four times to remove detergent and dried with acetone. Tests are picked from the mineral fraction with a dampened $10 / 0$ sable brush.

This method was found superior to floatation methods a forams of different densities or forams and ostracodes could be processed together. This is of particular concern because it is believed that previous workers may have missed arenaceous foraminifera because floatation techniques used were designed to recover lighter carbonate tests. An alternative is to use heavy liquids of higher density than are used for separation of carbonate tests. 


\section{Facies 1 Fauna}

This facies was barren in all samples examined. This is consistent with the proposed subaqueous outwash origin. The high energy of transport, high sediment load and rapid deposition all acted to prevent microfossil survival.

\section{Facies 2 Fauna}

Small numbers of the freshwater ostracode Candona cf. C. subtriangulata occur in the upper part of the laminated silt and clay (rhythmite) facies. The lower part was barren. Anderson et al. (1985) found Candona in association with Cytheissa lacustris and Limnocythere friabilis in cores from the Rideau Lakes area, and noted that the presence of $C$. subtriangulata and $C$. lacustris indicates a lake with few dissolved solids and depth up to $180 \mathrm{~m}$. This fauna is believed to coincide with the pre-A biofacies of Guilbault (1980), who examined a GSC core from Touraine, Québec and found 12 specimens or fragments of oligohaline ostracodes in rhythmites overlying diamicton.

\section{Facies 3 Fauna}

In the massive clay facies, faunal diversities are low. Populations are restricted to less than 7 or 8 species with 1 or 2 dominant species. Within the dominant species, abundance is also low.

The following foraminifera were found: Protelphidium orbiculare, Elphidium bartletti, Cassidulina islandica, Cassidulina crassa, Islandiella islandica and Dentalina pauperata. Dominant species are: Elphidium bartletti, Protelphidium orbiculare and Cassidulina crassa. Like other fine-grained facies, the foraminifera dominate the ostracodes, which are often absent. Based on this assemblage, the facies was deposited in brackish water (18-28\%) of shallow to moderate depth (10-30 m). Care must be exercised in bathymetric estimates, however, because restricted faunas could be washed into deeper water in times of high meltwater input. Where a great bathymetric range seems evident, faunal mixing may have occurred.

\section{Facies 4 Fauna}

The most abundant microfauna are found in this facies. Abundance and diversity of foraminifera and ostracodes increases along with macrofossil abundance, as shown by Cronin $(1977,1979)$. Dominant taxa include Elphidium sp. and Protelphidium sp. with minor numbers of Cibicides lobatulus and Guttulina sp., Pseudopolymorphina novanglie and Cassidulina crassa.

The environment represented by this assemblage is a nearshore environment, shallower than that of facies 3. Cronin (1979) noted that assemblages dominated by Elphidium and Protelphidium orbiculare represent nearshore environments less than $30 \mathrm{~m}$ deep. This interpretation is supported by the presence of Balanus fragments and juvenile Macoma balthica. Balanus prefers relatively high energy environments found in shallow water, and Macoma prefers water less than $10 \mathrm{~m}$ deep (Hillaire-Marcel, 1980). Salinities of $18-28 \%$ are indicated by this assemblage. Fillon and Hunt (1974) noted E. clavatum in salinites of $18-24 \%$ E . clavatum and $P$. orbiculare dominate in water of $22-28 \%$. They also noted summer water temperatures for this assemblage probably were less than or equal to $12^{\circ} \mathrm{C}$.

\section{SUMMARY AND DISCUSSION}

Facies descriptions, fauna and proposed paleoenvironments are summarized in Table I.

Facies 1 sediments represent subaqueous outwash deposits as described by Rust (1977) and Cheel and Rust (1980). The most common are interchannel sands and till flow facies. These have been deposited close to, or in contact with, glacier ice. There is no direct evidence to determine whether the water body at this time was marine or freshwater, but evidence indicates sediment directly overlying the subaqueous outwash was deposited in freshwater.

The fact that subaqueous outwash facies are found beneath freshwater rhythmites indicates that the facies forming the core of the ridges in the Ottawa area were deposited earlier than previously believed. Therefore, at least the ridge cores were deposited prior to submergence by the Champlain Sea. This is consistent with the evolution of sediment discharge in late glacial time. The high sediment loads required to produce ridge core facies would most likely have been available only in late glacial time, before sediment was dispersed and reworked by ice-marginal processes.

The rhythmites of facies 2 were deposited in a proglacial lake which preceded the Champlain Sea. This is shown by: 1) the presence of the deep, freshwater ostracode Candona; 2 ) the stratigraphic position of the rhythmites relative to the overiying, massive Champlain Sea clay; and 3) the finely laminated nature of the sediments. Sedimentological evidence indicates early influx of glacial meltwater, significant ice interaction, and deposition by episodic underflow currents following an uneven lake-bottom topography. This freshwater event was most likely shortlived. Rapid deposition produced fluid escape structures, slumping and microfaulting which resulted in chaotic bedding style and poor correlation of units.

\section{TABLE I}

Summary of facies characteristics and paleoenvironments

\begin{tabular}{|c|c|c|c|c|}
\hline Facies & Sediments & Dominant microfossil & Other fossil & Paleoenvironment \\
\hline 1 & $\begin{array}{l}\text { diamicton } \\
\text { cross bedded } \\
\quad \text { sand }\end{array}$ & barren & none & $\begin{array}{l}\text { glaciolacustrine? } \\
\text { subaqueous outwash }\end{array}$ \\
\hline 2 & $\begin{array}{l}\text { silt/clay } \\
\text { rhythmite }\end{array}$ & Candona sp. & none & glaciolacustrine \\
\hline 3 & $\begin{array}{l}\text { massive silty } \\
\text { clay }\end{array}$ & $\begin{array}{l}\text { E. bartletti } \\
\text { P. orbiculare } \\
\text { C. crassa }\end{array}$ & P. arctica & $\begin{array}{l}\text { glaciomarine } \\
\text { early Champlain Sea }\end{array}$ \\
\hline 4 & $\begin{array}{l}\text { mixed bedding } \\
\text { lenticular } \\
\text { flaser } \\
\text { wavy beds }\end{array}$ & $\begin{array}{l}\text { E. bartletti } \\
\text { P. orbiculare }\end{array}$ & $\begin{array}{l}\text { M. balthica } \\
\text { B. crenatus } \\
\text { M. edulis }\end{array}$ & $\begin{array}{l}\text { glaciomarine } \\
\text { nearshore Champlain Sea }\end{array}$ \\
\hline
\end{tabular}


The massive silty clay of facies 3 represents the first glaciomarine deposition in the Champlain Sea. The change from laminated to massive sediment reflects the increased salinity which prevented generation of underflow currents. Diminishing sediment concentration and increasing salinity resulted in marine bottom water with higher density than the inflowing glacial meltwater. Underflows were thus stopped, preventing the rhythmic alternation of underflow and overflow currents. The rarely observed laminated silt and clay resulted from occasional bursts of high sediment concentration.

Rapid evolution of the western Champlain Sea basin culminated in an offlap sequence represented by a coarsening upward series. As water level dropped, higher energy environments appeared and structures indicative of the intertidal zone were deposited: channels, gutter casts and mixed bedding types such as flaser, wavy and lenticular bedding and load casted ripples. With continued emergence of this coastline, energy levels increased and littoral deposits were created by reworking the previously deposited sediment (Harrison, 1977).

Early faunal growth was terminated by harsh environmental conditions, producing the spat-killed Portlandia arctica population. The microfaunal association of Islandiella-Cassidulina-Elphidium/Prote/phidium indicates a paleosalinity of $22-33 \%$ and water depths of 30 $100 \mathrm{~m}$. As water levels dropped, a higher energy intertidal environment developed and mixed bedding types of facies 4 were deposited. The macrofaunal assemblage of Balanus crenatus, Mytilus edulis and Macoma balthica indicates water depths of $10-30 \mathrm{~m}$. Mytilus gave a radiocarbon age of $10,100 \pm 100$, (BGS, 885) and Balanus an age of $10,500 \pm 180$ (BGS-886). The microfossil assemblage dominated by the Elphidium/Protelphidium complex also indicates a nearshore environment, shallower than that of facies 3 . On the basis of this assemblage, summer water temperatures were less than or equal to $12^{\circ} \mathrm{C}$, and paleosalinity of $18-28 \%$.

The change in faunal assemblages reflects, in part, a change from high density, high salinity bottom water in facies 3 to lower salinity bottom water in facies 4 . This has also been observed by Rodrigues and Richard (1986), and shows the dilution effect of meltwater mixing with the bottom water of the Champlain Sea.

\section{ACKNOWLEDGEMENTS}

This paper forms part of a Ph.D. dissertation conducted at the University of Ottawa. Financial support was provided by Natural Sciences and Engineering Research Council of Canada (NSERC) operating grants to H. M. French (A-8367), B. R. Rust (A-2672) and J. Veizer (A-9034), and by the Department of Geology, University of Ottawa. J. Terasmae, Brock University, kindly provided the radiocarbon dates. Helpful comments and discussion were provided at various stages by N. R. Gadd, R. Gilbert, B. R. Rust and J.-S. Vincent. Field assistance was given by W. G. Parkins, W. H. Pollard, and L. Trepanier. Figures were drafted by $P$. Brown and R. Hough, and photography by $\mathrm{G}$. Innes. The paper was greatly improved by the comments of J. England, F. F. Hein, and an anonymous reviewer.

\section{REFERENCES}

Allen, J. R. L., 1982. Sedimentary Structures: Their Character and Physical Basis. Elsevier Scientific Publishing Co., New York, 664 p.

Anderson, T. W., Mott, R. J. and Delorme, L. D., 1985. Evidence for a pre-Champlain Sea glacial lake phase in the Ottawa Valley, Ontario, and its implications. In Current Research, Part A. Geological Survey of Canada Paper, 85-1A: 239-245.

Banerjee, I., 1973. Part A: Sedimentology of Pleistocene glacial varves in Ontario, Canada. Part B: Nature of the grain-size distribution of some Pleistocene glacial varves in Ontario, Canada. Geological Survey of Canada, Bulletin 226, $60 \mathrm{p}$.

Cheel, R. J. and Rust, B. R., 1982. Coarse grained facies of glaciomarine deposits near Ottawa, Canada, p. 279-295. In R. DavidsonArnott, W. Nickling and B. D. Fahey, eds., Research in Glacial, Glacio-fluvial, and Glaciolacustrine Systems. 6th Guelph Symposium on Geomorphology, 1980.

Clark, P. and Karrow, P. F., 1984. Late Pleistocene water bodies in the St. Lawrence Lowland, New York and regional correlations. Geological Society of America Bulletin, 95: 805-813.

Cronin, T. M., 1977. Champlain Sea foraminifera and ostracoda: A systematic and paleoecological synthesis. Géographie physique et Quaternaire, 33: 107-122.

1979. Late Pleistocene benthic foraminifera from the St. Lawrence Lowlands. Journal of Paleontology, 53: 781-814.

1981. Paleoclimatic implications of Late Pleistocene marine ostracodes from the St. Lawrence Lowlands. Micropaleontology, 27 : 384-418.

Donovan, J. J. and Lajoie, G., 1979. Geotechnical implications of diagenetic iron sulphide formation in Champlain Sea sediments. Canadian Journal of Earth Sciences, 16: 575-584.

Fillon, R. F. and Hunt, A., 1974. Late Pleistocene benthonic foraminifera of the southern Champlain Sea: paleotemperatures and paleosalinity indications. Maritime Sediments; 10: 14-18.

French, H. M. and Rust, R. B., 1981. Stratigraphic investigation, South Gloucester special waste disposal site. Final Report, Contract OSU81-00313, Environment Canada, NHRI, 30 p.

Gadd, N. R., 1961. Surficial geology of the Ottawa area: Preliminary report. Geological Survey of Canada Paper 61-19.

1962. Surficial geology of the Ottawa map-area, Ontario and Quebec (includes map 16-1962). Geological Survey of Canada, Paper 62-16.

- 1971. Pleistocene geology of the central St. Lawrence Lowlands. Geological Survey of Canada, Memoir 359.

- 1977. Offlap sedimentary sequence in Champlain Sea, Ontario and Quebec. In Report of Activities, Part A, Geological Survey of Canada Paper, 77-1A: 379-380.

Graham, B. W. and Jackson, R. E., 1982. Quaterly Progress Report, South Gloucester Project, April 1982. Environment Canada, NHRI River Road Labs, $71 \mathrm{p}$.

Guilbault, J.-P., 1980. A stratigraphic approach to the study of the lateglacial Champlain Sea deposits with the use of Foraminifera. Ph.D. thesis, Aarhus University, 294 p.

Harrison, J. E., 1977. Coastal studies in the Ottawa area. Report of Activities, Geological Survey of Canada, Paper 77-1A: 59-60.

Hillaire-Marcel, C., 1980. Les faunes des mers post-glaciaires du Québec: quelques considérations paléoécologiques. Géographie physique et Quaternaire, 34: 3-59.

Johnston, W. A., 1916. Late Pleistocene oscillations of sea level in the Ottawa Valley. Geological Survey of Canada, Museum Bulletin, 24.

1917. Pleistocene and Recent deposits in the vicinity of Ottawa with a description of the soils. Geological Survey of Canada, Memoir 101.

Jopling, A. V. and Walker, R. G., 1968. Morphology and origin of rippled-drift cross lamination, with examples from the Pleistocene of Massachusetts. Journal of Sedimentary Petrology, 38: 971 984. 
Lajtai, E. Z., 1967. Origin of some varves in Toronto, Canada. Canadian Journal of Earth Sciences, 4:633-639.

Naldrett, D. L., 1986. Glacigenic clays of the Ottawa Valley. Ph. D. thesis, University of Ottawa, $218 \mathrm{p}$.

1988. The late glacial-early glaciomarine transition in the Ottawa Valley: Evidence for a glacial lake? Géographie physique et Quaternaire, 42: 171-179.

Naldrett, D. L. and Rust, B. R., 1984. Rhythmic sedimentation in early marine deposits of the Champlain Sea near Ottawa, Canada. Geological Association of Canada, Program with Abstracts, 9: 92.

Richard, S. H., Gadd, N. R. and Vincent J.-S., 1977. Surficial materials and terrain features, Ottawa-Hull, Ontario-Québec. Geologica Survey of Canada Map 1425A.
Rodrigues, C. G. and Richard, S. H., 1986. An ecostratigraphic study of Late Pleistocene sediments of the western Champlain Sea Basin, Ontario and Quebec, Geological Survey of Canada, Paper 85-22, $33 \mathrm{p}$.

Romanelli, R., 1970. A study of the Pleistocene sediments in two sand pits near Ottawa. B.Sc. thesis, University of Ottawa, $45 \mathrm{p}$.

Rust, B. R., 1977. Mass flow deposits in a Quaternary succession near Ottawa, Canada: diagnostic criteria for subaqueous outwash. Canadian Journal of Earth Sciences, 41: 175-184.

1982. Flow tills in Late Quaternary subaqueous outwash deposits of the Champlain Sea near Ottawa, Canada. Geological Association of Canada, Program with Abstracts, 7: 78.

Wagner, F. J. E., 1984. Fossils of Ontario, Part 2: Macroinvertebrates of the Champlain Sea with a listing of nonmarine species. Royal Ontario Museum, Life Sciences Miscellaneous Publications, 64 p. 